\title{
Evaluation of Spinach Germplasm for Resistance to a New Race (Race 4) of Peronospora farinosa f. sp. spinaciae
}

\author{
L.P. Brandenberger ${ }^{1}$, T.E. Morelock ${ }^{1}$, and J.C. Correl1 ${ }^{2}$ \\ University of Arkansas, Fayetteville, AR 72701 \\ Additional index words. Spinacia oleracea, S. turkestanica, S. tetrandra, downy \\ mildew, Peronospora effusa
}

\begin{abstract}
Spinach germplasm (707 accessions) from collections from six countries were screened for resistance to race 4 of the downy mildew pathogen Peronospora farinosa f. sp. spinaciae; these collections contained germplasm that originated from 41 countries. The predominant species examined was Spinacia oleracea $L$., however, eight accessions of S. turkestanica Iljin and two accessions of $S$. tetrandra Stev. were also tested. About 40 seedlings of each accession were inoculated. The cultivar St. Helens was included as a susceptible control in each test. The majority of accessions tested $(>98 \%)$ were susceptible to race 4 . Nine accessions exhibited some resistance to race 4 (9\% to $38 \%$ of the seedlings within an accession were resistant), and two accessions, CGNO 9546 and SPI 82/87, exhibited a high level of resistance $(60 \%$ and $80 \%$ resistant, respectively). Resistance identified in several of the accessions in this study may be useful for breeding for race 4 resistance.
\end{abstract}

Downy mildew, caused by the fungal pathogen Peronospora farinosa (Fr.) Fr. f. sp. spinaciae Byford [ $=P$. effusa (Grev.) Ces.] (Brandenberger et al., 1991b), is a destructive disease of spinach worldwide. In the United States, downy mildew has been reported from all major spinach production areas (Brandenberger et al., 1991a; Halsted, 1890; Jones, 1982; Smith et al., 1961; Zink and Smith, 1958). Under favorable environmental conditions, epidemics can progress very rapidly, and an entire crop may be lost in a short time. In addition to direct yield losses, the downy mildew pathogen can reduce the quality of processed and fresh-market spinach (Richards, 1939). Four physiologic races (races 1, 2, 3, and 4) of $P$. farinosa f. sp. spinaciae are recognized on spinach (Brandenberger et al., 1991a; Jones, 1982; Jones et al., 1956; Zink and Smith, 1958), with race 4 having recently been identified in the United States (Brandenberger et al., 1991a; Correll et al., 1990). Historically, downy mildew on spinach has been controlled by the use of cultivars with resistance to a race of $P$. farinosa f. sp. spinaciae (Jones et al., 1956; Scheewe and Philipp, 1986; Smith, 1950; Smith et al., 1962) conditioned by a single gene. Many of the cultivars in use today have combined singlegene resistance to races 1,2 , and 3 (Brandenberger et al., 1991a; Eenick, 1976; Jones,

Received for publication 24 June 1991. Accepted for publication 28 May 1992. We thank 0. Schuler, L. Wasilwa, B. Davis, A. Mirlohi, and M. Fiely for technical assistance. This work has been supported in part by Allen Canning Co. and the California Spinach Mildew Committee. The cost of publishing this paper was defrayed in part by the payment of page charges. Under postal regulations, this paper therefore must be hereby marked advertisement solely to indicate this fact.

'Dept. of Horticulture.

${ }^{2}$ Dept. of Plant Pathology.
1982; Smith, 1950; Smith et al., 1962). The purpose of this study was to test available accessions of spinach from the United States Plant Introduction collection and from foreign collections (Table 1) for resistance to an isolate of race 4 of $P$. farinosa f. sp. spinaciae.

The isolate of $P$. farinosa $\mathrm{f}$. sp. spinaciae used for the screening tests was obtained from a commercial spinach field of 'Jade' from Oxnard, Calif., in 1990. Race identification of this isolate was determined by inoculation tests on the differential cultivars Viroflay, Nores, Califlay, St. Helens, and Polka (Brandenberger et al., 1991a). 'St. Helens' and 'Polka' are resistant to races 1, 2, and 3 (Brandenberger et al., 1991a; Jones, 1982); 'Califlay' is resistant to races 1 and 3 (Scheewe and Philipp, 1986; Smith and Zahara, 1956); 'Nores' is resistant to races 1 and 2 (Scheewe and Philipp, 1986); and 'Viroflay' is susceptible to races 1,2 , and 3 of downy mildew (Scheewe and Philipp, 1986; Smith, 1950). All of the differential cultivars were susceptible to race 4 (Brandenberger et al., 1991a). The isolate used in the currently reported study was used in a previous one in which 34 commercial spinach cultivars were shown to be susceptible to race 4 (Brandenberger et al., 1991a).

The isolate was maintained on young seedlings of 'St. Helens'. Spores were collected by placing symptomatic leaves with evidence of sporulation in a $250-\mathrm{ml}$ widemouth container containing $30 \mathrm{ml}$ of chilled (4C) distilled water. The closed container was vigorously shaken for $\approx 1 \mathrm{~min}$. The suspension was then filtered through two layers of cheesecloth. The spore concentration was determined using a hemacytometer and adjusted to between 0.8 and $2.0 \times 10^{5}$ spores/ $\mathrm{ml}$.

Plants were inoculated by applying 10 to $15 \mathrm{ml}$ of the spore suspension onto a con- tainer of seedlings. The spore suspension was applied from four directions with a Sigma model S 3257 spray unit (Sigma, St. Louis). Inoculated plants were then moved into an unlighted dew chamber and incubated at 14 to $17 \mathrm{C}$. To ensure infection, plants were reinoculated 12 to $15 \mathrm{~h}$ later with the same spore suspension, which had been stored at 4C. For each inoculation test, spores were sprayed onto $2 \%$ (water) agar in petri dishes to verify viability of the inoculum. Plants were given a total dew period of 24 to $36 \mathrm{~h}$. Following the dew period, plants were moved to a growth chamber and incubated for 4 to 6 days at 15 to $22 \mathrm{C}$ with a $12 \mathrm{~h}$ light/ $/ 2 \mathrm{~h}$ dark cycle. Plants were watered daily with a dilute nutrient solution consisting of Peters 20N-20P-20K fertilizer with trace elements at a rate of $120 \mathrm{ppm}$. The incubation period depended on the onset of disease symptoms.

Seed of the accessions and 'St. Helens' were pregerminated by soaking in distilled water for $48 \mathrm{~h}$ at $8 \mathrm{C}$, drained and rinsed with distilled water, then placed on four layers of filter paper in a petri dish to absorb excess water. The seed were incubated at $8 \mathrm{C}$ for 48 to $72 \mathrm{~h}$, at which time the radicle had reached a length of 3 to $5 \mathrm{~mm}$. Pregerminated seed were planted either in $31 \times 23 \times 11-\mathrm{cm}$ polystyrene containers for inoculation tests or in $7.5 \times 7.5 \times 10$-cm 18 -cell flats for producing inoculum. The polystyrene containers were modified to allow for bottom drainage by using hardware cloth that supported the growing medium $2 \mathrm{~cm}$ above the bottom of the container. A 5-cm layer of peat-lite growing medium (Fissons Sunshine Mix 1, Vancouver, B.C.) was applied to the top of the hardware cloth. The inoculation tests were set up in a randomized completeblock design. Due to the limited availability of seed, tests were set up with only two replications. Each box (replication) contained five rows of plants, with each row being a different accession; every other box contained one row of the susceptible 'St. He-

Table 1. Spinach germplasm collections used for resistance screening tests to race 4 of Peronospora farinosa f. sp. spinaciae.

\begin{tabular}{|c|c|c|}
\hline Collection ${ }^{x}$ & $\begin{array}{l}\text { Species in } \\
\text { collection }\end{array}$ & $\begin{array}{l}\text { No. } \\
\text { accessions } \\
\text { tested }\end{array}$ \\
\hline Netherlands & $\begin{array}{l}\text { turkestanica, oleracea, } \\
\text { tetrandra }\end{array}$ & 287 \\
\hline United States & oleracea & 255 \\
\hline Japan & oleracea & 24 \\
\hline Germany & oleracea & 133 \\
\hline Italy & oleracea & 5 \\
\hline Russia & oleracea & 3 \\
\hline
\end{tabular}

${ }^{2}$ Netherlands = Institute for Horticultural Plant Breeding (IVT), Wageningen; United States = U.S. Dept. of Agriculture, North Central Regional Plant Introduction Station, Ames, Iowa; Japan = National Institute of Agrobiological Resources, 21-2 Kannondai, Tsukiba, Ibaraki; Germany- = Zentralinstitut für Genetik und Kulturpflanzenforschung der Akademie der wissenschaften der DDR Gatersleben. Italy $=$ Consiglio Nazionale delle Ricerche Istituto de1 Germoplasma, Bari; Russia $=$ The N.I. Vavilov All-Union Institute of Plant Industry 44, St. Petersburg, Russia. 
Table 2. Reaction of selected spinach plant accessions to race 4 of Peronospora farinosa f. sp. spinaciae.

\begin{tabular}{|c|c|c|c|c|c|c|c|c|}
\hline \multirow[b]{2}{*}{ Collection $^{2}$} & \multirow[b]{2}{*}{ Accession } & \multirow{2}{*}{$\begin{array}{c}\text { Geographic } \\
\text { origin }\end{array}$} & \multirow[b]{2}{*}{ Species } & \multicolumn{2}{|c|}{$\begin{array}{c}\text { No. plants } \\
\text { resistant/no. } \\
\text { plants tested }\end{array}$} & \multicolumn{2}{|c|}{$\begin{array}{c}\text { Resistant } \\
\text { plants }^{\mathbf{x}}(\%)\end{array}$} & \multirow{2}{*}{$\begin{array}{l}\text { Susceptible } \\
\text { St. Helens" } \\
(\%)\end{array}$} \\
\hline & & & & Test 1 & Test 2 & Test 1 & Test 2 & \\
\hline Netherlands & CGNO 9546 & $?$ & turkestanica & $19 / 24$ & $33 / 41$ & 79 & 80 & 100 \\
\hline Germany & SPI $82 / 87$ & Iraq & oleracea & $23 / 36$ & $19 / 34$ & 64 & 56 & 100 \\
\hline \multirow[t]{2}{*}{ Netherlands } & CGNO 9634 & $?$ & oleracea & $19 / 46$ & $34 / 93$ & 41 & 37 & 100 \\
\hline & CGNO 9611 & Syria & oleracea & $11 / 36$ & $9 / 31$ & 31 & 29 & 100 \\
\hline United States & 183246 & Egypt & oleracea & $11 / 36$ & $6 / 25$ & 31 & 24 & 100 \\
\hline Italy & 200891 & $?$ & oleracea & $8 / 42$ & $8 / 36$ & 19 & 22 & 100 \\
\hline \multirow[t]{2}{*}{ United States } & 220686 & Afghanistan & oleracea & $12 / 37$ & $1 / 27$ & 32 & 4 & 100 \\
\hline & 211632 & Afghanistan & oleracea & $9 / 40$ & $3 / 21$ & 22 & 14 & 100 \\
\hline \multirow[t]{3}{*}{ Netherlands } & CGNO 9612 & Egypt & oleracea & $6 / 31$ & $12 / 87$ & 19 & 14 & 100 \\
\hline & CGNO 9636 & Afghanistan & oleracea & $8 / 53$ & $11 / 101$ & 15 & 11 & 100 \\
\hline & CGNO 9533 & Iran & oleracea & $3 / 19$ & $7 / 96$ & 16 & 7 & 100 \\
\hline
\end{tabular}

${ }^{z}$ The country that a particular collection was obtained from; see Table 1 for more detailed information.

y The number of plants in an inoculation test that exhibited no evidence of sporulation on either the cotyldeons or true leaves/number of plants of that particular accession that were included in a test.

*Percentage of plants that exhibited no evidence of sporulation on either the cotyledons or true leaves.

wTotal number of susceptible 'St. Helens' plants for the two inoculation tests divided by the total number of plants included in the tests.

lens'. There were $\approx 20$ seedlings of each accession per replication.

Seed were covered with a thin layer of commercial planting mix (Metro-Mix 200, W.R. Grace, Cambridge, Mass.). All plants were grown in the greenhouse at 15 to $25 \mathrm{C}$. Plants were watered daily with the nutrient solution previously described; they were inoculated when the first true leaves were $\approx 2$ $\mathrm{cm}$ long (10 to 24 days after planting).

Initial symptoms appeared as either small $(\approx 0.5 \mathrm{~cm}$ in diameter), diffuse, yellow-green chlorotic lesions or as a general chlorosis of cotyledons and leaves. After symptoms were observed (5 to 8 days after the first inoculation), plants were returned to the dew chamber and incubated at 14 to $17 \mathrm{C}$ for 12 to $24 \mathrm{~h}$ to induce sporulation.

Seedlings were rated for disease incidence by examining the cotyledons and the first true leaves of each plant with the aid of a Opti Visor magnifier, model DA-7 (Donegan Optical, Kansas City, Mo.). Disease incidence was recorded as both the mean percentage of plants with at least one cotyledon exhibiting evidence of sporulation and the mean percentage of plants with at least one true leaf exhibiting evidence of sporulation. Plants were considered to be resistant if no evidence of sporulation was found on either the cotyledons or true leaves. Plants were considered susceptible if evidence of sporulation was found on either the cotyledons or true leaves.

In the overall inoculation tests, 'St. Helens' consistently exhibited a disease incidence of $\geq 90 \%$, but in inoculation tests with resistant accessions, it exhibited a disease incidence of $100 \%$ (Table 2). The majority of the accessions (> 98\%) were considered susceptible to race 4 of $P$. farinosa f. sp. spinaciae. Eleven accessions exhibited putative resistance, with $\geq 15 \%$ of the seedlings within an accession exhibiting no disease symptoms on either the cotyledons or true leaves in the first screening test. These accessions were selected for retesting, using the previously described protocol. However, pregerminated seed were planted in 18-cell flats (three seeds per cell) to facilitate transplanting for seed production after disease screening.

Nine of the 11 spinach accessions that were retested had a mean percentage of resistant plants of $\geq 15 \%$ (Table 2). The two most resistant accessions, CGNO 9546 and SPI $82 / 87$, had a mean percentage of resistant plants for both tests of $80 \%$ and $60 \%$, respectively. Interestingly, the majority of the accessions that were identified as being resistant originated from countries in the Middle East, which is thought to be where spinach was first cultivated (Jones and Rosa, 1928). Of the 11 accessions that were retested, nine originated in either Afghanistan, Egypt, Iraq, Iran, or Syria.

The plants that were identified as being resistant in our inoculation tests showed no evidence of infection by $P$. farinosa f. sp. spinaciae on either the cotyledons or true leaves. This resistant reaction is identical to that of other spinach cultivars that have resistance inherited as a single dominant gene to previously described races (races 1,2 , and 3 ) of the downy mildew pathogen (Scheewe and Philipp, 1986; Smith, 1950; Smith et al., 1961, 1962). We do not know if the resistance identified in our inoculation tests is conditioned by a single dominant gene. Although the accessions that exhibited resistance to race 4 have not been tested for resistance against other races of $P$. farinos $a \mathrm{f}$. sp. spinaciae, it is not uncommon for resistance genes to be genetically linked in spinach (Eenick, 1976; Scheewe and Philipp, 1986; Zink and Smith, 1958).

The race 4-resistant accessions have a wide range of horticultural characteristics varying from deeply lobed to smooth leaf margins and semi-flat to flat leaf characteristics. The seed of the accessions range from spiny to round, with some accessions segregating for this characteristic. There is considerable variability within the resistant accessions, which should provide adequate material for spinach breeders. Limited quantities of seed of most of the resistant accessions are available from the authors. A complete listing of all of the spinach accessions and their reactions to race 4 is available upon request.

\section{Literature Cited}

Brandenberger, L.P., J.C. Correll, and T.E. Morelock. 1991a. Identification and cultivar reactions to a new race (race 4) of Peronospora farinosa f.sp. spinaciae on spinach in the United States. Plant Dis. 75:630-634.

Brandenberger, L.P., J.C. Correll, and T.E. Morelock. 1991b. Nomenclature of the downy mildew fungus on spinach. Mycotaxon 41:157-160.

Correll, J.C., S.T. Koike, L.P. Brandenberger, M.C. Black, and T.E. Morelock. 1990. A new race of downy mildew threatens spinach. Calif. Agr. 44:14-15.

Eenick, A.H. 1976. Linkage of Spinacia oleracea L. of two race-specific genes for resistance to downy mildew Peronospora farinosa f.sp. spinaciae Byford. Euphytica 25:713-715.

Halsted, B.D. 1890. Some fungous diseases of the spinach. New Jersey Agr. Expt. Sta. Bul. 70.

Jones, H.A. and J.T. Rosa. 1928. Truck crop plants. McGraw-Hill, New York.

Jones, H.A., D.M. McLean, and B.A. Perry. 1956. Breeding hybrid spinach resistant to mosaic and downy mildew. Proc. Amer. Soc. Hort. Sci 68:304-308

Jones, R.K. 1982. Occurrence of race 3 of Peronospora effusa on spinach in Texas and identification of sources of resistance. Plant Dis. 66:1078-1079.

Richards, M.C. 1939. Downy mildew of spinach and its control. Cornell Univ. Agr. Expt. Sta. Bul. 718

Scheewe, P. and R.R. Philipp. 1986. Resistance to races 1, 2 and 3 of Peronospora spinaciae in a synthetic variety of spinach (Spinacia oleracea L.). Z. Pflanzenzüchtg. 96:154-160.

Smith, P.G. 1950. Downy mildew immunity in spinach. Phytopathology 40:65-68.

Smith, P.G. and M.B. Zahara. 1956. New spinach immune to mildew. Calif. Agr. 10:15.

Smith, P.G., R.E. Webb, and C.H. Luhn. 1962. Immunity to race 2 of spinach downy mildew. Phytopathology 52:597-599.

Smith, P.G., R.E. Webb, A.M. Millett, and C.H Luhn. 1961. Downy mildew on spinach. Calif. Agr. 15:5.

Zink, F.W. and P.G. Smith. 1958. A second physiologic race of spinach downy mildew. Plant Dis. 42:818. 